シンボル等価の検討”, 1998 年映情学年次大 2-2, pp. 17-18 (July 1998)

6）浜住，伊藤，宮沢：“広帯域信号用帯域分割型 ダイバーシチ合成受信方式の特性一OFDM 移動受信における特性改善例一”, 信学技報, SST 96-7, SAT 96-21, RCS 96-31, pp. 37-42 (June 1996)

7）福森，富家，樋口: “移動受信時における OFDM 伝送の周波数ダイバーシテイ受信特 性の室内実験結果”, 映情学技報, 22, 19, BCS 98-5, pp. 25-30 (Mar. 1998)

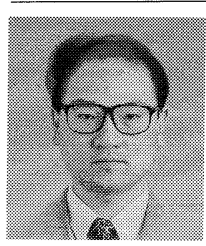

廣野 ニ郎
1988 年, 早稲田大学電気 工学専攻修士課程修了。同 年, (株) フジテレビジョン 入社. 現在，技術局企画開 発部に勤務し, 最新放送技 術に関する調查研究に従 事. 1995 年より，兼ねて (株)次世代ディジタルテレ ビジョン放送システム研究 所に出向し, 地上ディジタ ル放送システムの研究に従 事. 正会員.

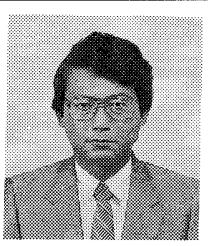

1976 年, 電気通信大学応 用電子工学科卒業. 同年, NEC に入社. 1995 年よ り,(株)次世代デジタルテ レビジョン放送システム研 究所にて, 移動体向け放送 の研究に従事。正会員

\title{
4-3 地上ディジタル放送用試験装置
}

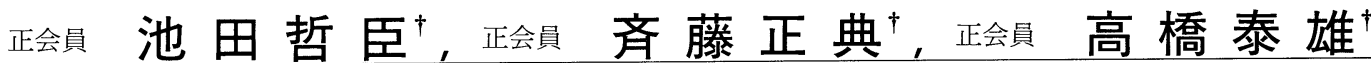

\section{1. まえがき}

地上ディジタル放送の伝送方式は, 平成 9 年 9 月に電気通信技術審議会に おいて「地上デジタルテレビジョン放 送暫定方式の原案(伝送部分)」として とりまとめられた。この暫定方式原案 は, OFDM 伝送方式を採用している が，移動体受信サービスや階層化伝送 など，新たな技術的要素が加えられて いる。

現在，標準化に向けて，方式の検証 と各種伝送パラメー夕に対する性能評 価を行っている。ここでは，暫定方式 原案に沿って試作した実験装置の概要 と室内実験結果の一部を紹介する。

\section{2. 実験装置の概要}

\section{1 全体構成}

実験装置の系統を図 1 に示す。実験 装置は, MPEG-2 TS再多重装置, 統合制御装置，送信装置および受信装 置で構成される。受信装置は，広帯域 受信装置(帯域幅約 $5.62 \mathrm{MHz}$ を復調 可能) と部分受信装置(帯域幅約 432 $\mathrm{kHz}$ を復調可能)の 2 式があり，広帯 域受信および部分受信の実験が可能と なっている。

†株式会社次世代デジタルテレビジョン放送シ ステム研究所

"A Transmission Test Equipment for Digital Terrestrial TV Broadcasting" by Tetsuom Ikeda, Masafumi Saito and Yasuo Takahashi (Advanced Digital Television Broadcasting Laboratory, Tokyo)
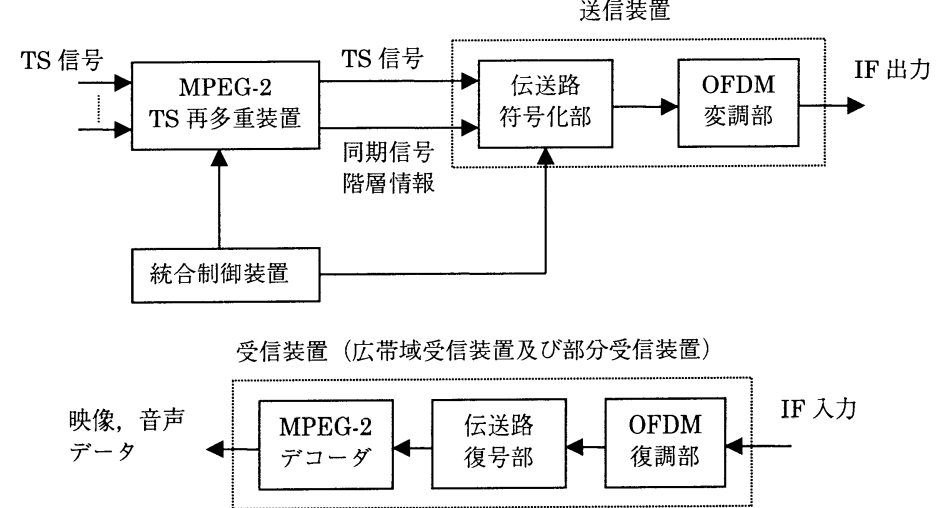

図 1 実験装置の系統

\subsection{MPEG-2 TS 再多重装置と統} 合制御装置

MPEG-2 TS 再多重装置は，符号 化された 4 系統のTS (Transport Stream)形式の番組(映像, 音声, デ ー夕など)を入力し， MPEG-2 システ ム規格(ISO/IEC 13818-1) に準拠して 再多重を行い，1系統の TS 信号とし て出力する.

入力された各 TS 信号は, PID (Packet Identifier)によって分離さ れ，それぞれ指定された階層バッファ に入力される。ここで, PCR(Program Clock Reference)を含むパケッ トは, STC(System Time Clock)再 生部に送られ，クロック再生が行われ る。このクロックは, 後で PCR の生 成に利用される。

これら階層バッファに蓄積されたパ ケットは同一階層ごとに集められ，
PCR, PSI (Program Specific Information), SI (Service Information)の 各信号と共に多重化される。このよう に，分離・再合成を行う構成により， 番組コンポーネントをそれぞれ異なる 階層で伝送することが可能となる。

多重化は，有効パケットと無効パケ ット(ヌル TSP)の並び順を定めた地 上波特有の多重フレームを用いて行わ れる。多重フレームは OFDM 伝送フ レームと 1 対 1 に対応しており，モー ドとガードインターバルによりパケッ 卜数が決められている.

統合制御装置は，TS再多重装置お よび送信装置を制御する端末で, Windows 95 を OS とするパソコンと ソフトウェアから構成される。階層構 成および伝送パラメータをGUI (Graphical User Interface)を用いて 入力し, 多重フレームや TMCC 


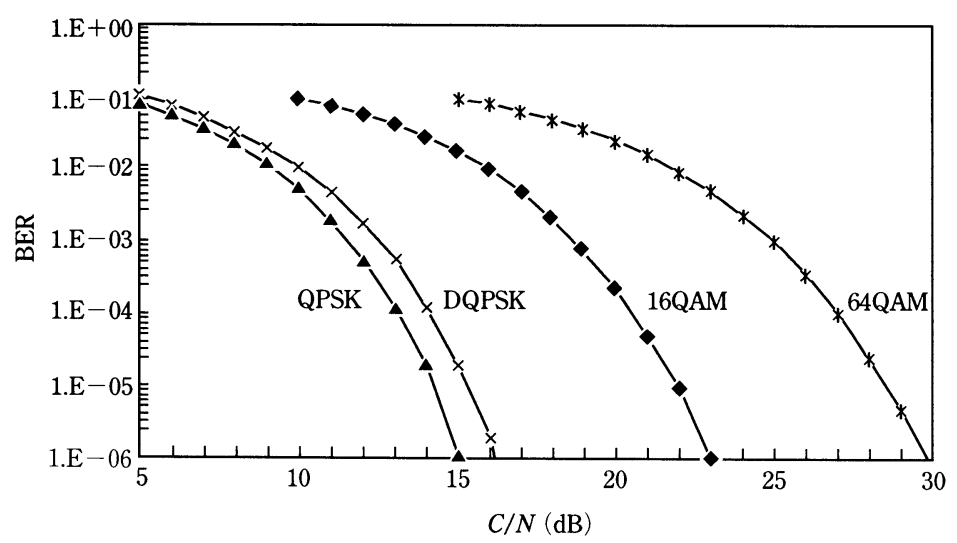

図 2 各変調方式のビット誤り率特性

(Transmission and Multiplexing Configuration Control) 信号などの設 定を行う。

多重フレームは, 各種パラメータの 組合せにより約 9,000 万通りのパター ンが存在する。これらのパターン計算 と PSI およびSIの設定を行い, TS 再多重装置に転送する。送信装置に対 しては, TMCC 信号を生成し, 伝送 パラメータの設定を行う。

\section{3 送信装置と受信装置}

送信装置は，伝送路符号化部扔よび OFDM 変調部から構成される. 伝送 路符号化部は，TS 信号を入力し，工 ネルギー拡散, 周波数抒よび時間イン タリーブ，詥り訂正符号化などの処理 を行う。この後, デー夕信号に CP (Continual Pilot)信号, SP (Scattered Pilot) 信号, TMCC 信号を多重 化し, OFDM のフレームを構成する. $\mathrm{CP}$ 信号は周波数の同期に, SP 信号 は伝送路応答の等化に, また, TMCC 信号はフレーム同期と受信機 の制御に用いられる。

OFDM 変調部は, フレーム構成さ れた信号をIFFT(逆FFT)により変 調し, ガードインターバルを付加した 後, 直交変調および周波数変換回路で $37.15 \mathrm{MHz}$ の IF 信号として出力す る.

受信装置は, OFDM 復調部, 伝送 路復号部および MPEG-2 デコーダか
ら構成される. OFDM 復調部および 伝送路復号部は, 送信装置と逆の処理 を行い，1系統の TS 信号として出力 する. 暫定方式原案では，周波数同期 やタイミング同期用の特殊なシンボル （ヌルシンボルやチャープシンボルな ど)は用いていない.このため, 同期 再生はガードインターバルの相関と CP，TMCC 信号を用いて行ってい る。

また，受信装置には実験の評価・確 認用として以下のモニ夕端子を備えて いる。

(1) スペクトラム

(2) コンスタレーション

（3）各種タイミング信号

（4）ビット誤り率

最終的に, 伝送路復号部より出力さ れたTS 信号は, MPEG-2 デコーダ により, 映像, 音声, デー夕信号とし て出力される.

\section{3. 室内実験結果}

室内実験では, ガウス雑音, マルチ パス，フェージング環境下に扔ける特 性取得を行っている。

一例として, 図 2 にガウス雑音環境 下における各変調方式のビット誤り率 特性を示す．伝送パラメー夕は，モー ド 1 ，ガードインターバルは $1 / 8$ を用 いている。これらのデータはシミュレ ーション值とよく一致し, 実験装置は

期待通りの動作をしている.

また，周波数や夕イミングなどの同 期に関しても, 前述した特殊なシンボ ルを使わずに良好な性能が得られてい る。

\section{4. むすび}

地上ディジタル放送の方式検証を目 的に開発された実験装置の概要を述べ た．現在も標準化作業は進行中であ り，関東地域に打ける大規模実証実 験，全国 7 地域で行われるパイロット 実験なども計画されている。これらの 実験により，OFDM 伝送方式を用い た場合の特性が明らかになるであろ う。

今後, 地上ディジタル放送の特徴を 活かした移動体受信サービス, マルチ メディアサービスなど魅力ある放送サ 一ビスの実現が期待される。

(1998 年 8 月 4 日受付)

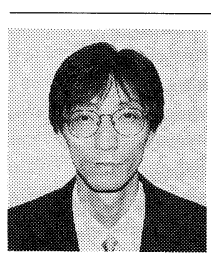

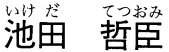
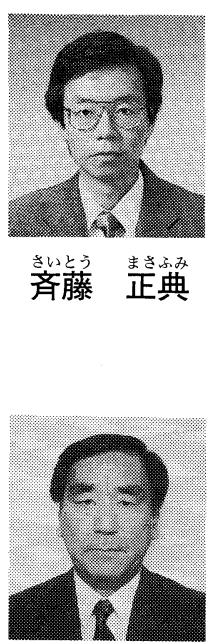

嗃橋 泰雄
1984 年, 室蘭工業大学電 子工学科卒業。同年, NHK に入局. 旭川放送局 を経て、1989年より,同 放送技術研究所に勤務。デ イジタル変復調方式, 適応 信号処理の研究に従事。 1995 年より, DTV - Lab に出向. 地上ディジタルテ レビ放送の研究に従事. 正 会員.

1979 年, 東京大学工学部 電子工学科卒業. 同年, NHK に入局．岡山放送局 を経て, 1982 年ょり, 同 放送技術研究所に勤務し, デー夕放送, 有料放送, デ イジタル放送伝送方式の研 究に従事. 1995 年より, DTV-Labに出向. 現在, 同社第 1 研究室長. 工学博 士. 正会員.

1967 年, 京都大学工学部 電子工学科卒業. 同年, (株) 東芝入社. 以降, 無線 通信機器設計, 衛星放送シ ステムの開発, OFDM 伝 送システムの開発に従事。 1995 年より, (株)次世代 デジタルテレビジョン放送 システム研究所第 2 研究室 長を兼務，現在に至る。正 会員. 